\title{
A Study of Iranian EFL University Lecturers' Practice of Code Switching in English as Foreign Language Instruction
}

\author{
Gholamhossein Shabani (Corresponding author) \\ Department of English, Roudsar and Amlash Branch \\ Islamic Azad University, Roudsar, Iran \\ E-mail: G.Shabani762@gmail.com
}

Ramin Asadi Jamnani

Department of English, Tonekabon Branch, Islamic Azad University, Tonekabon, Iran

Davood Mashhadi Heidar

Department of English, Tonekabon Branch, Islamic Azad University, Tonekabon, Iran

Received: March31, 2016 Accepted: April24, 2016 Published: May 1, 2016

doi:10.5296/jse.v6i2.9247 URL: http://dx.doi.org/10.5296/jse.v6i2.9247

\begin{abstract}
This study aimed at investigating where and the purposes for which code-switching is used by Iranian EFL lecturers in universities as foreign languageinstruction. The data of this study were gathered from two sources: six EFL university lecturers from three local universities where they taught English as EFL instruction. Theywere interviewed individually regarding the use of code-switching in their classrooms in order to reveal their purposes of using this strategy as well as their participants' understandings of code-switching as a language teaching strategy. The interviews took 30-40 minutes each. The interviews were finally transcribed and the main themes were coded to answer the research questions; the second group of participants was students as native speakers of Persian. Ninety undergraduates from the three universities were randomly chosen from among those students majoring in TEFL. They were majoring in the first grade of the academic program. To this end, an eleven-item questionnaire was given to them to elicit their responses for the contexts and the reasons for which code-switching was preferred.The data from interview with EFL lecturers as well
\end{abstract}




\section{Macrothink}

those of the students' responses were analyzed qualitatively and quantitatively using SPSS, respectively, to determine where and for what purposes codes-switching were applied or practiced in EFL classrooms. The findings of the study indicated that their code-switching habits were connected to what was being taught. Their code-switching had to do with efficiency in their teaching and how to make it easier for the students to understand what they were teaching.

Keywords: Code-switching, EFL, EFL classroom instruction, Foreign Language, University lecturers 


\section{Introduction}

Code-switching is a phenomenon that exists in bilingual communities where individuals have or find the opportunity to use two or more languages to communicate. Being able to speak more than one language, bilinguals can code-switch and use their languages as resources to find better ways to convey meaning.Code-switching is employed in the repertoires of most bilingual people and in most bilingual communities. Switching from one language to another language is effective in continuously establishing EFL classroom communication. Code-switching can be practiced by teachers by integrating it into the activities whose purpose may be to teach a second language or facilitate teaching the language. Skiba (1997) and Sert (2005) valued code switching as being a supporting element in the communication of information and in social interaction which therefore serves for communicative purposes in the way that it is used as a tool for transference of meaning.

Bista (2010) argues for the importance of the use of code switching in EFL classroom by holding that it is helpful to serve better in English immersion setting where the choice of a code-switching or the variety of it, depending upon its context, supplies clarification when a word or phrase is not known. Likewise, Bista (2010) pointed out that code exchange occurrences are initiated and welcomed in the class by EFL teachers and learners and may promote English competency provided that the frequency is not excessive. Skiba, (1997) explained that by switching from one language to another one at pre-determined points in conversation and having students get in pairs to switch languages, teachers assist learners in learning and understanding each other's language. Teachers also sometimes begin a subject matter of a lesson in one language, then switch to another language, encouraging and even force the learners in EFL classroom to listen carefully and comprehend both languages.

Sert (2005) recognized the application of code-switching as being be effective, in particular, when L2 teachers or language trainers seek to motivate students to learn further, to engage them in further understanding, and maintain attention, and create a classroom environment to be more conducive to language acquisition. This issue turns out an interesting topic and a critical area of concern for researchers to draw attention to and explore. He, furthermore, conceptualized that code-switching appears to be an effective strategy in L2 classroom interaction in that it plays role in the clarification of meaning and transfer of the knowledge to students in an efficient way.

Trudgill (2000) introduced code-switching in a bilingual community context as speakers' inspiration and tendency to switch to manipulate or influence or define the situation as they wish, and to convey nuances of meaning and personal intention. In this notion, in terms of its functions in the discourse of bilingual individuals, it may be assumed that code-switching can be intentionally used and sought for self-expression and is a way of modifying language for the sake of personal intentions. The function of code-switching in a bilingual community context is believed to build intimate interpersonal relationships among members of a bilingual community. Drawing on this view, it is said that code-switching occurrence is a means for establishing linguistic solidarity, in particular, between /among the individuals who possess and share the same ethno-cultural identity. 
Low proficient students appreciate code-switching in their EFL classes as beneficial in order that they can achieve better comprehension, in particular, when seeking equivalent comprehension, and go along with classroom procedures (Tien \&Liu, 2006). Or, as Cook (1991) put forth, code-switching can be applied as a teaching strategy or method for teaching second languages, or it can be a tool for introducing language patterns to facilitate language development to L2 learners in abilingual community context. It is perceived that code-switching is still valued as a positive indication of the learning progress.

In the light of these arguments, it was suggested that code-switching in L2 language classroom is not a blockage or deficiency in learning a language; in other words, code-switching may not be considered as a sign of defect when it is used by teachers within the classroom, but rather it is considered as a useful strategy in classroom interaction considering the idea that its exploitation is to make meaning clear and to transfer the knowledge to students in an efficient way. Cook (2001) mentioned that it is important not to prevent students from using their first language but to encourage them to use the second language in as many situations as possible and to find out when and why code-switching should occur. Regarding the effects of code-switching on vocabulary learning, Lin (2013:205-207) indicated that code-switching serves to increase and expand learners' capacity of cognitive processing made. Lin reported that processing words comprehension both through their explanation in the learners' L2 and a translation into the students' L1 involve further cognitive effort, meaning that the students are able to learn new vocabulary more thoroughly.

The present study aimed at investigating where and for what purposes code-switching is used by Iranian EFL teachers in universities. In order to reach this aim, the following research questions were set forth:

\section{Research Questions}

Q.1: When and why do teachers code-switch in the English classroom?

Q. 2:What language do students prefer in the English classroom?

Q.3:Is there agreement between the teachers' code-switching patterns and the students' preferences?

\section{Review of the Literature}

\subsection{Definition of Code-switching}

According to Heller (1988), code-switching happens when a person combines two languages in a single sentence or a dialogue. Valdes-Fallis (1978) asserted that people can mix words, phrases and clauses. Communicative strategy is the communicative interaction between two language codes among people who donate to those precise codes. In such exchange, several social and linguistic elements guide the way communicative strategy exhibits itself. In regular conversations among bilinguals, communicative strategy contains eighty-four-percent single word switches, ten-percent-phrase switches, and six-percent-clause switching (Skiba, 1997). 
Communicative strategy arises in many forms. The first kind of language switching is named mechanical switching, thatlooks accidentally. This sort of communicative strategy is also recognized as code mixing. Code mixing occurs when the speaker cannot recall an expression, but can remember it in a dissimilar language. Another type of communicative strategy, identified as code changing, is identified byeasy intrasentential shifts, changingemphasis from one language to another. It is inspired by situational and stylistic variables, and the aim behind the switch between two languages is important (Lipski,1985).

\subsection{Reasons for the Occurrence of Communicative Strategies}

The reasons for communicative strategy are chiefly social. Olmedo-Williams (1981) defined nine classes of communicative strategy based on her research on language mixing in classroom situations. These classescomprise emphasis, sociolinguistic play, clarification, accommodation, lexicalization, attracting attention, regulating behavior, and miscellaneous switches. She held that lexicalization and clarification are connected to individuals' capability torepresent themselves better in another language on a certain topic. Communicative strategy is also impressed by the setting and by the activity. In unceremonious situations, students are more probable to code switch. Furthermore, Goodman and Goodman (1979) realized that students often employ language switching in spoken language, but infrequently in written language. Because spoken language is less formal than written language, this appears to advocate Olmedo- Williams' deduction that students code switch less in formal conditions.

Liebscher and Dailey-O'Cain (2005) proposed that foreign language learners switch back to their native language when they realize they face hindrances in the target language dialogue. Sert (2005) found someclasses of code-switching in a foreign language classroom. The first one is named Equivalence, which happens when the student doesn't have the ability in the target language, for instance when $\mathrm{s} /$ he feels that $\mathrm{s} /$ he is not skilled enough to clarify something in the target language. The student, therefore, in its placeemploys lexical items from the native language. This procedure is, based on Sert (2005), a kind of defensive mechanism. The second category is named Floor-holding. Here the students employ native language words to fill breaks in the dialog to evade breaks or open spaces in the conversation. Sert asserted that this process may have a negative effect on language learning if students carry on with this kind of code-switching for a long period of time. They may be unable to find the capability of fluency in a conversation. The third class is named Reiteration. Pupils employ thisrole to strengthen and illuminate a message. Sert asserted that students may replicate words and phrases in their native language because they sense they did not elucidate a message in the target language but also to display the teacher that $\mathrm{s} / \mathrm{he}$ has comprehended the task or content in the situation. Heredia and Brown (2005) believedthat people frequently do it to be understood better. As said by Yule (2010), there is one thing called Communicative competence, which means that L2 learners attempt to employ the foreign language properly. Rababah (2002) said that we can find other strategies within communicative competence. One such strategy is called interlanguage communication strategy, saying that L2 learners follow a range of different types of strategies to get their message across. The learners wish toform their message rapidly to avoid communication difficulties. Characteristic behaviors would be: employing words from their native language, 
mumbling, repeating sentences and words, attempting to avoid definite words which they may find demanding, rearticulating words and sentences, asking someone else for the accurate word or sentence, and correcting themselves through self-correction as Rababah names it.

Teachers can follow communicative strategy indiverse activities to instruct a second language. For instance, students can make up two-member groups and switch languages deliberately in conversation; it aids them to learn each other's language. Teachers can begin a lesson in one language, and then switch to another one while attempting to make the students understand both languages (Skiba, 1997).

\subsection{Research on Code-switching}

Code-switching in foreign language classroom has latelyreceived considerable debate. Simon (2001) asserted that the research of code-switching with regard to foreign language learning has developed. The language classroom has been stimulating for researchers. As stated by Milroy and Muysken (1995), code-switching in the foreign language classroom is an international phenomenon; there has been research on this in a number of countries including the United States, South America, Canada, Europe, and Southeast Asia.

We have observed some research on positive and negative facets of code-switching in foreign language classrooms. Some researchers believe that code-switching can be a benefit in L2 (second language) learning whereas othersbelieve that code-switching merely has drawbacks. Gumperz and Hernandez-Chavez (1972) suggested that people believed thatthe ones who code-switch make a mess out of the conversation and cannot be fluent in the language properly. Thomas (2001) held that in some societies code-switching is even considered as something intolerable. Nevertheless, some researchers have a positive view on code-switching. Sert(2005) proposed that code-switching probably has a positive outcome. By means of code-switching, weconstruct a bridge from the identified, our native language to the unidentified, target language. He asserted that this possibly has an essential influence on foreign language learning. Sert (2005)believed that code-switching in foreign language classrooms is beneficial. He says thatit is aninstrumentto construct linguistic solidarity, particularly between people who have the same ethno-culturalidentity. Additionally, Liebscher and Dailey-O'Cain (2005) pointed out that teachers should cheer code-switching in place ofbanning it in foreign language classrooms. They also proposed that teachers should consider code-switching as abenefit and that the employment of L1 (first language) is respectable and meaningful to motivate L2 acquisition. They consider thistype of classroom as "a community of practice".

Ellis (1994)maintainedthat, even though exposure to the target language can guarantee success, the exposure may not be effective in every classroom. It has been debated that English only classroom would only result in frustrationbecause the input is unintelligible to the learners (Lai, 1996; Widdowson, 2003).

Code-switching should not be regarded as a symbol of flaw in the teacher. As an alternative, it is a careful strategy used by the teachers. Code-switching should be permitted whenever 
necessary with some learners in particularconditions (Schweers, 1999). The literature has shown the diverse positive and easing functions of code-switching accepted by both the teachers and learners including explaining new vocabulary, relaxing the learners, explaining grammar, talking about class tasks and assessments and establishing contact with learners.

The study by Duff and Polio (1990) is one of the first endeavors to determine the functions of communicative strategies in language classrooms. Theyexhibited that there was anextensivevariation among teachers concerning thequantity of time they employed L1 fluctuating from 10 to 100 percent.

In a supplementary study, Polio and Duff (1994) wanted to catch on the occasions in which teacher communicative strategy occurred. The analysis of data exhibited that teachers resorted to students' L1 to employadministrative vocabulary (e.g., exam, term, quiz, etc.), clarifygrammatical elements, construct rapport with students, presentunidentifiedvocabulary, remedy students' absence of understanding, and obtaintrainings from students as to how appropriatelyemploy English (which was students' L1). A distinctivecharacteristic ofthis study which weakens the generalizability of the results is that students and teachers did not share identical first language, anoccurrence not very usual in language teaching settings across the world.

The research conducted by Rolin-Lonziti and Brownlie (2002) disclosed that teachers employed English for translation, and communicative goals like managing the classroom and showing teachers' state of the mind. Similarly, the maximum density of teachers' employment of L1 could be seenunder thecircumstances of grammar description.

Mugla and Seedhouse (2005) differentiated between teacher initiated communicativestrategy and teacher induced communicative strategy. The previousone refers to the conditionwhere the teacher himself/herself switches to the L1 while the latter happens when teacheremploys one language to induce learners to speak the other language. The findings exhibited that teachers initiated communicative strategy when they did not obtain any response to their questions from the students, when they wished to translate an item into L1, when they aimed to supply a prompt for L2 employment, and when they came across technicaldifficulties and wanted to give strong instructions to students.

Based on a case study, Edstorm (2006) showed that L1 was used for explaining grammar, managing classroom, compensating understandingcollapse, talking about the culturaldimensions of the target society, constructing rapport and linking with students, and translating problematic parts. Once more, the methodologicaldifficulty here was that the researcher/teacher was conscious of the aim of the research which might have affected her classroom practices.

One of the newest studies that probed the functions of teacher communicative strategy was conducted by Qian et al. (2009) who identified two generalclasses of teachers' communicative strategy: methodological and social. The former, employed when teachers were oriented toward the efficiency of instruction, was utilized for L1 translation, explanation, emphasizing, and competence in the case of absence of enough time. Cases of social 
code-switching contained the employment of L1 for admiration, encouragement, and discontentment of students' behavior. Likewise, in some cases teachers switched to L1 toachieve a combination of both methodological and social functions.

\section{Methodology}

\subsection{Participants}

The essential data of this study weretaken from EFL university lecturers and university students. To do the study, sixEFL university lecturers from threelocal universities where they taught English as EFL instruction were selected, including two lecturers from each university. The lecturers were teaching conversation courses in their universities. The lecturers' experience in teaching English as an EFL instruction ranged fromsix to twelve. They were graduated from universities with a master's degree or doctor's degree in English Education, English Literature or English Linguistics and all had training in English pedagogy. They taught students of different education stages and dissimilar majors. Their academic ranking differed from professor to assistant professor. The lecturers were interviewed individually regarding the use of code-switching in their classrooms in order to reveal their purposes of using this strategy as well as whether they were using it as a conscious strategy or not. These interviews, also known as play-back sessions (Harris, 2006), were used to tap into the participants' understandings of code-switching as a language teaching strategy. The interviews took 30-40 minutes each. The interviews were finally transcribed and the main themes were coded to answer the research questions.

Thesecond group of participants was students as native speakers of Persian. Ninety undergraduates from the three universities were randomly chosen from among those students majoring in TEFL. They were majoring in thefirstgrade of the academic program. Theywere from three local universitiesin Iranand portrayed different families, study contexts, cognitive styles and experiences.

\subsection{The Instruments for Collecting the Data}

The instruments for collecting data in this study included (a) questionnaire, and (b) interview session with the English lecturers (Appendices 1 \& 2).

The first tool used in this study was an oral interview including seven questions (Johansson, 2013). The data for the current study were the answers given in the interviews in which the lecturers expressed their personal opinions on employing English in their teaching, and reasons for which they or the students practice L1 in some cases. The interview did not cover a lot of questions since this would result in too much data that could not be advantageous for the discussion. The lecturers did not receive the question before the interviews, and they were carried out following one of their observed lessons. The interviews were conducted in English to get the most intricate answers which would be easier to discuss and compare with the other lecturers s' answers.

The second tool employed in the present study was a questionnaire (Johansson, 2013). The purpose of the questionnaires was to enable a comparison of teachers' code-switching 
behavior. The questionnaire investigated EFL students' attitudes towards code-switching in different classroom situations and also included some background information. The questions were of the multiple-choice type allowing the studentsto choose only one answer. It totally comprised eleven questions in multiple-choice form, through which the candidates were asked to provide their response to each of the questions by choosing one answer.

\subsection{Technique for Data Validity (Validation of Data) and Reliability}

In terms of the validity of the study, the important aspect was to see whether it provideda clear picture of what was studied. A triangulation was conducted to confirm the dependability of data or information by looking at the source of data recurrently to arrive at the same inference on the phenomena observed. This model of data validation waswell-matched with Hopkins's (1993)model by which he mentioned that the technique of triangulation can enhance the validity of a category while confirming data.All interviews were conducted in the same way which was in accordance with Johansson and Svedner's (2010) model. With regards to this, all interviews were carried out using the exact questions. In order for the study to maintain its reliability, the data concerning reasons to eventual code switching was considered as means for discussion.

\subsection{Data Analysis}

In this study, questionnaire and structured interviews were employed to collect the data. To analyze the gathered data, descriptive analysis was utilized. The data gathered through interviewwere analyzed qualitatively. The analysis aimed to find the reasons for which English lecturers practice English and other languages code switching in EFL instruction in the classroom. Likewise, the data obtained from the questionnaire were inserted into the SPSS 19 for further analysis. The descriptive statistics of frequencies and percentages were computed to answer the research questions.

\subsection{Result}

\subsubsection{The Teachers' General Views on Code-switching}

Commonly it is believed that code switching is an unintentional process meaning that the speaker may move from one language to another subconsciously. It is a matter of investigation to find out what general rules govern this process. The results of the interview indicated the followingpoints:

\subsubsection{No Code-switching in the Classroom}

Some lecturers believed that No! Persian should not be present in the English classroom! This was their instant response to code-switching in the classroom. Saber explained that:

English is the target language and I typically tell the students to use only Englishin the classroom.

They were of the idea that some students believe itis tough but they must be told that they have few chances to talk in English, so they shouldn't lose these opportunities. They must be reminded that they can speak Persian all through breaks and in all other classes. 
Theselecturers wanted their students to follow English in their classes and avoid Persian as far as possible. This seems to be a rule in which the only exception is translation exercises. Javad, being very optimistic regarding code-switching, avoided astraight answer with respect to her overalloutlook of code-switching where he asserted that:

English must definitely occupies the class time as much as possible,nonetheless; the fact is that it is our second language. Consequentlywe can't be so sure regarding the extent of L1 employment in the classroom.

Cala was the only teacher who really emphasized that she rarely code-switched and that she tried to code-switch as little as possible. She thought it is important for the students to hear and speak English as much as possible. If the students do not understand she keeps on explaining until they understand. She thinks that the students can learn from this method and realize that there is always more than one way of saying something, a strategy that can be useful when they speak English themselves.

\section{5. 1.2. Code-switching as a Useful Strategy for Teaching}

Some of the participants claimed that code-switching is a beneficial strategy in teaching English in their settingbecause it employs the shortest and easiest path to teach a topic,particularly, when dealing withgrammatical points:

Majid: Through the use of mother tongue we can express our intention using less words... particularly concerning low level students, since just using English will be too time consuming .

Ahmad Reza: The mere use of English cannot guarantee the acquisition of the rules of grammar. Students will get a low mark if they do not understand what is being taught, therefore to improve students grades code-switching is a necessity. For the purpose of real world, English seems superior but concerning the syllabus requirements code-switching improves learning.

Based on Qing (2010), teachers follow code-switching for translating or illuminating the important messagesover the process of clarifying new vocabulary or grammar points. As Majid and Ahmad Reza alsohighlighted, code-switching assists the teachers to elucidate meaning of grammar points in addition to savingthem priceless time to be in line with the time limits of the syllabus. As Samira believed through avoidance of justEnglish words, they are saving time. Additionally, code-switching permits the teacher to expressaccurate meaning helping boost learning (Gumperz, 1982). Possibilities of misinterpretation are reducedthrough employing native language in teaching the grammar points. As Tien and Liu (2006) proposed, code-switching is advantageousin the direction ofobtaining better understanding. To transfer the new content and meaning code-switching is employed as a link to transfer accurate meaning and comprehension andconsequently enhance precision. If students were to employ it in their everyday communications, code-switching can be reflective of theirease, vocabulary and competence (Eldridge, 1996).

The prevailing idea among lecturers was thatPersian should not be considered as a part of an English classroom. This could expressive of the fact that that can be functional only under 
certain circumstances but that they try to avoid code-switching in general. Both Majid and Ahmad Reza code-switch to an extensivedegree when they teach grammar and Samiraexplicates that she always speaks Persian whileteaching grammar.In the classroom,she declares that Persian is the language of teaching grammar. Fateme claims that since knowledge of Persian language structure can facilitate learning English structures code-switching can be an appropriate procedure in this regard. In case grammar is taught in English,the students might face a range of difficulties including learning a new collection of complex terminology. Hamid is the only teacher being very transparent regarding her code-switching. He specifies that while teaching grammar code-switching to Persian onlyhappened under particular conditions including explaining the content and goal of the $t$ certain grammatical structure and clarifying the instructions on them.

Regarding the grammatical structures of English sentences, it can be summed up that they are reasonablyunlike Persian sentences. In the grammar classes, the teacher may need to employ the native language to make those points understandable to the students such areas include intricate and puzzling grammar topics such as subject-verb agreement, clause patterns, learning articles, pronoun reference etc. Consequently, grammarcan be taughtby means of comparing and contrasting the grammatical elements of the two languages that practically show to be profitable. In the same line,English vocabulary can be acquired by studentsthrough translating English words.

\section{5. 1.3. Affective Dimension of Code-switching}

It seems that code-switching is leading to a number of affective issues in the classroom. Onesuch theme is motivation. Fateme is of the idea that it cheers them when they attempt to understand. As a result, they take part. It offers motivation to them. This is arotationin which the ones understanding a topic take part more and therefore they attain better results. Through gettinggood results, their motivation increases. In addition,based on Gumperz (1982), code-switching is putting an end to the status gap between the teacher and the students. As Samira expressed,code-switching to the students' mother tongue during instruction unstiffens the airsince they offer lexicon which otherwise cannot be found in English, i.e., English lacks equivalent words having identical meaning.Through code-switching to the learners' language, the teacher gives the message that he/she can understand the students' language and,therefore, exhibits his familiarity with their culture in comparison with a foreigner that cannot speak their language. It creates a warm atmosphere in the classroom that results in good will and support. Fateme states that when used for this purpose, code-switching enhances students'self-confidence. Students feel closer to their teachers and feel that they are supported. They becomemore eager to break the limits of confidence that restricts learning the new language as they know that if they cannot produce correct utterances in English and they use Persian, their teacher will understand them.

\subsubsection{The Circumstances to Avoid Code-switching}

Despite talking about so many benefits that code-switching brought to classroom practice, participants also mentioned some shortcomings in exercising code-switching. As Ahmad Reza pointed out, code-switching is not so effective while being used for advancedlevel 
students.In contrast, he believed it is a necessity for students at lower levels. In this regard, a number of reasons can be pointed out including constructing confidence or elaborating meaning. Code-switchingis not an impressive strategy for high level learners since they possessthe competence to understand the simple structures of English as the target language. Therefore, they do not feel to refer back to Persian to clear up meaning or recognize instructions.

As Cole (1998) asserted, teachers can employ students' previous first language learning knowledge to enhance their perception of the new language. As a result, code-switching should only be followed when offering topics, elaborating instructions, and employing students' current awareness of their mother tongue. Thelecturers in the study contend that code-switching should only be done while offering grammar points. The objective is to ascertain that studentsrealize the rules before using them in communication. As Maidmentioned, when students recognize the rules, they can apply them properly. Over this process, in exercising their language skills, code-switching is pointlessbecause teachers are receiving feedback from their students concerning their learning:

Samira: We are not going to present explicit grammatical structures to the learners, so there remains no reason for code switching. Listening and speaking would receive priority for acquiring the language skills.

The only place in which code-switching can occur is the classroom. So, according to Samira, it can be advantageous for learners at the class level. Fateme claimed that since in actual communication with native speakers they cannot make use of their mother tongue, code-switching could have a negative effect on their performance in the future. These conditions support Eldridge's position (1996) who proposed that learners cannot be certainwhether theirrecipients will share understanding of their mother tongue in the real world. Nonetheless, next disadvantageexpressed by Samira wasthat when students become accustomed to the code-switching, they anticipate it all the time. They believe that their teacher must follow their mother tongues everywhere. This is in line with Sert's (2005) position, claiming that students' code into their native language resulting in negative academic outcomes as the students will have imperfectcontactwith the foreign language discourse. In other words, students in the language classroom require the teacher to code-switch in every condition and for everything being taught. This may give rise todependent students who need teacher's code-switching for explanations.

Consequently, Anders', Bella, Cala, and Dana were of the view that code-switching should be avoided, while Erica's answer was more of an explanation as to why she would code-switch. What made her different from the rest of the teachers was that her attitude towards code-switching was much more open and she code-switched for social reasons to a much larger extent than the other teachers. 


\subsubsection{Students' Tendencies for Language Preference in EFL Classrooms}

This section illustrated the results of the questionnaire. The main purpose of the questionnaire was to examine what language the 90 students as the participants in this study preferred to covert to in various classroom situations.

In response to question 1, seventy percent (70\%) of the EFL students showed their preferences for the use of English when learning grammar. Twenty percent $(25 \%)$ of the students, however, preferred their EFL language-English-, and Persian was the least preferred language to be used as a medium for explaining grammatical points in their classrooms $(5 \%)$.

In the case of the question 2 of the questionnaire, almost sixty-five percent $(65 \%)$ of the whole students preferred their teachers to refer to English in times of providing instructions such as those for exams, material preparation announcement and so on. Persian was the least preferred language for giving instructions (5\%), and a combination of both English and Persian was chosen a language for instructions for about $30 \%$.

Regarding the question 3 on the questionnaire, whenever the students in EFL classrooms needed to be informed about their test, fifty percent (50\%) of the total students asked their teachers to refer to a combination of both English and Persian. Thirty percent of the participants made their choice of English (30\%), and the language which was least preferred was the students' native language (20\%).

With regard to question 4 concerning the usefulness of this device (code-switching) in clarifying and announcing the result of a test, fifty-five percent $(55 \%)$ of the respondents preferred their teachers to convert into English to make them known of the results of the tests in classrooms. Twenty-five percent (35\%) of the respondents chose a combination of both languages while the least preferred language for the notification of test result was concerned with the application of Persian (10\%).

Regarding the question 5, being concerned with the candidates' preferred language or languages as a tool for discussing students' grades, the most preferred language for this purpose belonged to the combination of both English and Persian (32\%), and the language which was of the second priority was English (62\%). To this end, just seven percent $(6 \%)$ of the total respondents referred to Persian.

For the sake of the clarity of representation and space management, the results of the responses to the questions 1 to 5 are illustrated in Figure 1. 


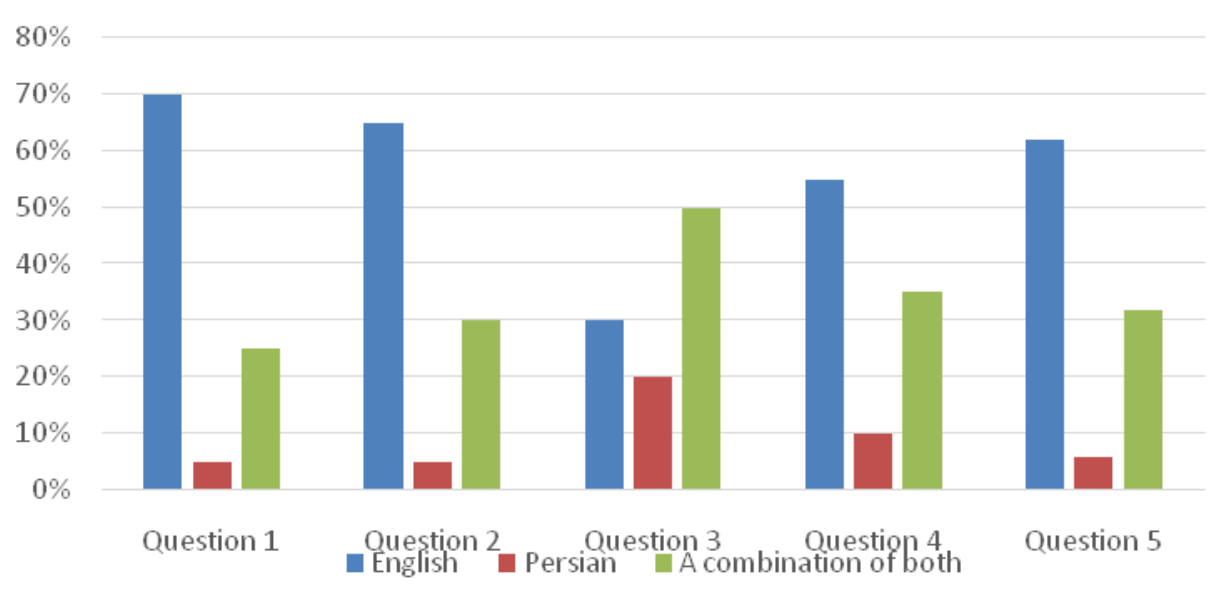

Figure 1. Schematic Representation of the Responses to the Questions 1-5

While presenting new lessons, topics, concepts and their instructions to the learners, 68 percent of the respondents answered that they asked their teachers to clarify the ambiguous points in English through using several strategies for elucidation like repetition, reformulation, clarification, exemplification and so on. 10 percent of them tried to ask their classmates in their first language, and 22 percent preferred their teachers to intentionally or unintentionally switch codes from English to Persian. Code switching was regarded as an influential tool in clarifying any sort of misperception or misapprehension concerning any topic. The result of the responses to the questions 6is illustrated in Figure 2.

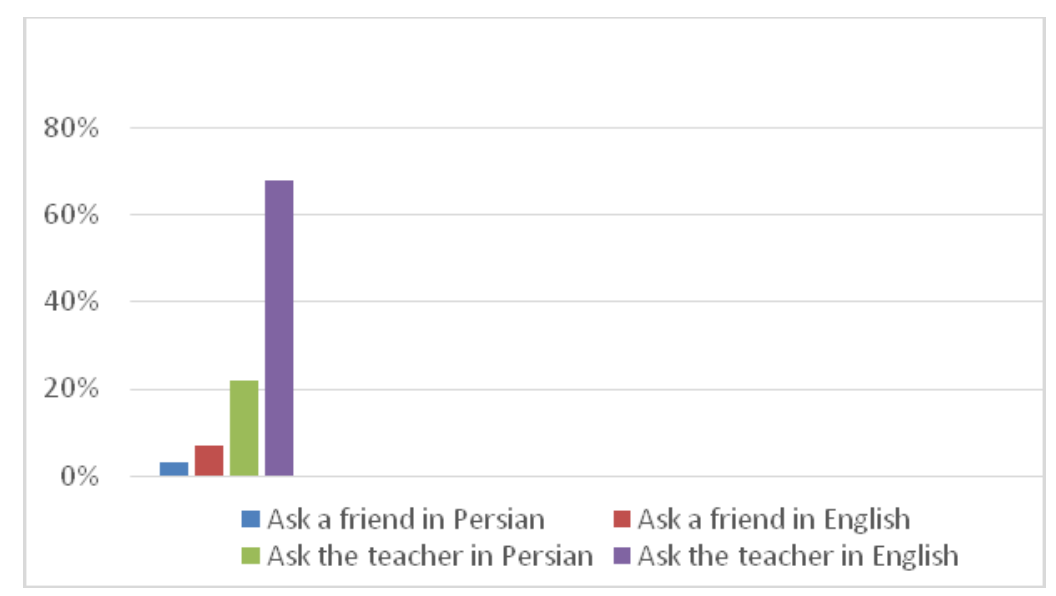

Figure 2. Schematic Representation of the Responses to Question 6

The question 7 dealt with the students' view on how they understood the teacher whenever he/she spoke with them using their first language. The total number of the responses given to this category revealed that they seemed to understand as well when they were spoken in English; 74 percent showed their preference for this item while 25 percent of the respondents showed that they understood better as they were spoken into their own language and just one 


\section{IIMacrothink}

percent $(1 \%)$ were of the view that they would understand less. The result of the responses to the questions 7 is illustrated in Figure 3.

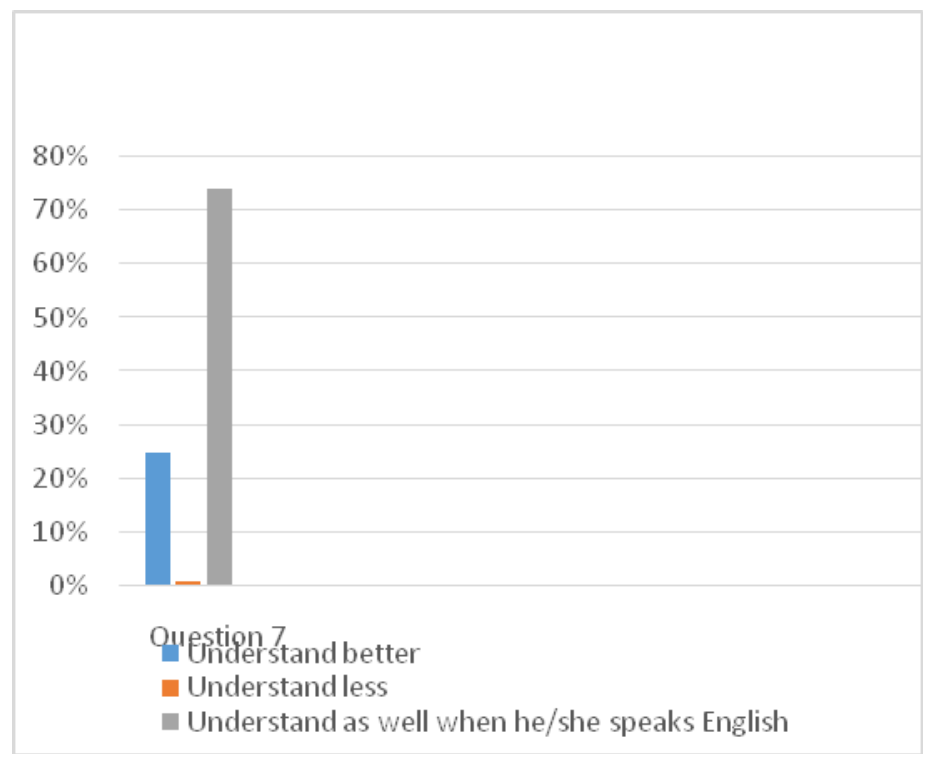

Figure 3. Schematic Representation of the Responses to Question 7

In response to question 8 , 'When I ask a question in Persian, I want my teacher to answer me in ...., Fifty-five (55\%) said that they preferred both which entailed the application of codes switching, seventy-five said that they wanted their teacher to use English (35\%), and ten percent said they preferred their teacher to use Persian (10\%). The result of the responses to the questions 8is illustrated in Figure 4.

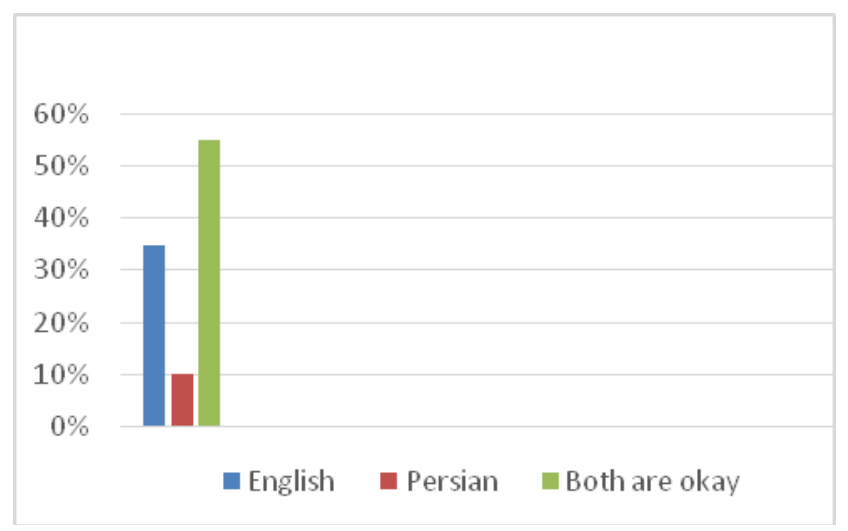

Figure 4. Schematic Representation of the Responses to Question 8

In response to question 9, 'If my teacher explains something that I don't understand, I want $\mathrm{him} /$ her to ....', forty-eight percent $(65 \%)$ answered that they preferred their teacher to explain the unclear instructions in English but in a rather different way so that the explanation 


\section{Macrothink}

Journal of Studies in Education

ISSN 2162-6952

2016, Vol. 6, No. 2

could be understandable, and fifteen percent (15\%) responded that they preferred to explain the unclear instructions in their own first language. Around twenty percent $(20 \%)$ said that they wanted their teacher to clarify the unclear explanations through repeating the explanation. The result of the responses to the questions 9is illustrated in Figure 5.

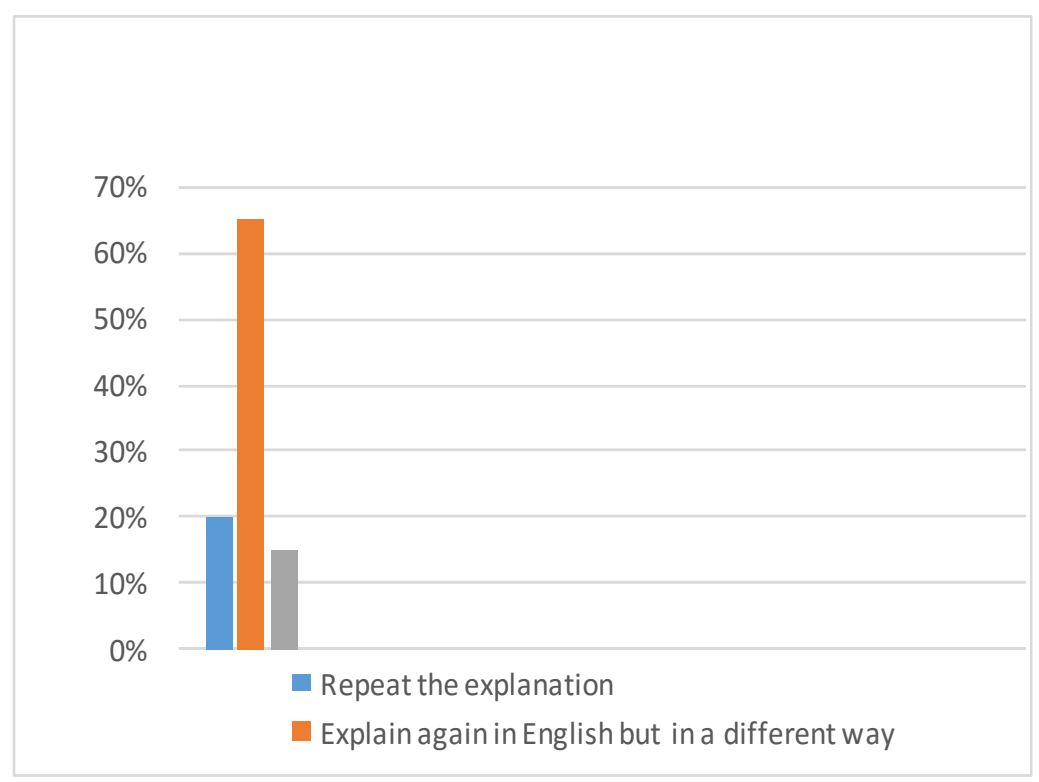

Figure 5. Schematic Representation of the Responses to Question 9

The question number 10 sought to clarify what language (s) the students demanded their teacher to speak when they were involved in an EFL classroom. To this end, eighty-eight percent $(88 \%)$ responded that their teacher had better speak mainly English but sometimes Persian. In addition, twelve percent (12\%) expected their teacher to allow them to speak in an only English-teaching classroom context. The result of the responses to the questions 10is illustrated in Figure 6.

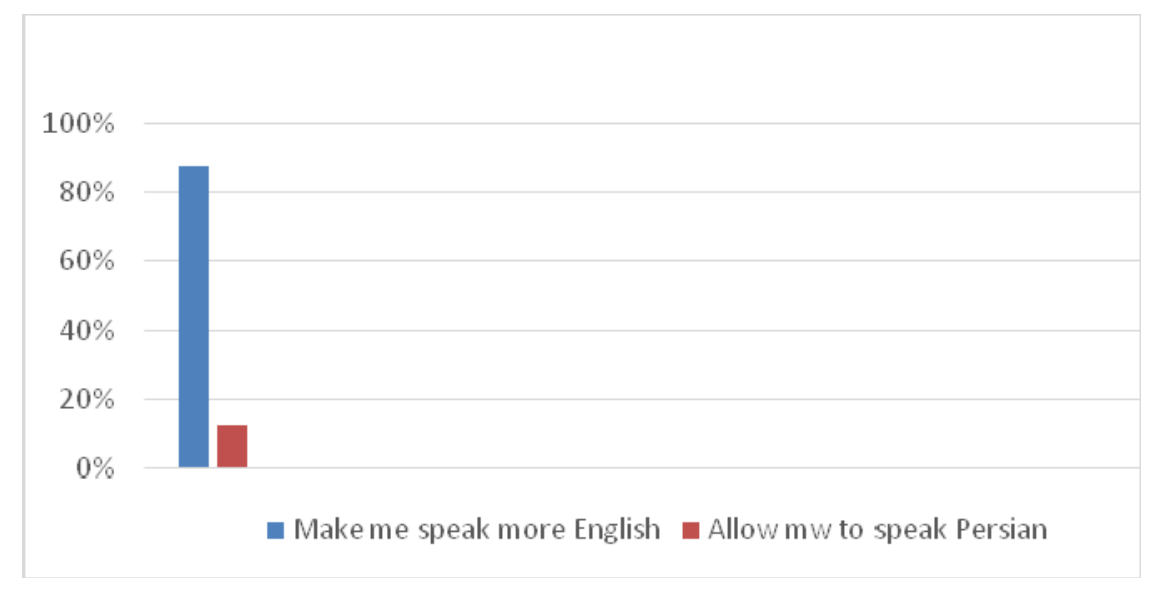

Figure 6. Schematic Representation of the Responses to Question 10 


\section{Al Macrothink}

To elicit the respondents' idea on what language(s) their teacher normally favored as the language for interaction and instruction, the students provided four categories of responses. A combination of mostly English and sometimes Persian was the most preferred languages during classroom instruction. The least preferred language during the classroom instruction was merely Persian. Statistically, fifty-four percent (54\%) of the respondents answered that their teacher preferred to speak mainly English but sometimes Persian, forty-five percent (45\%) chose that their teachers had better speak only English, none of them ( $0 \%)$ favored that teachers speak only Persian, and finally this figure was just one percent (1\%) about those respondents who expected their teacher to use mainly Persian but sometimes English. The result of the responses to the questions 11 is illustrated in Figure 7.

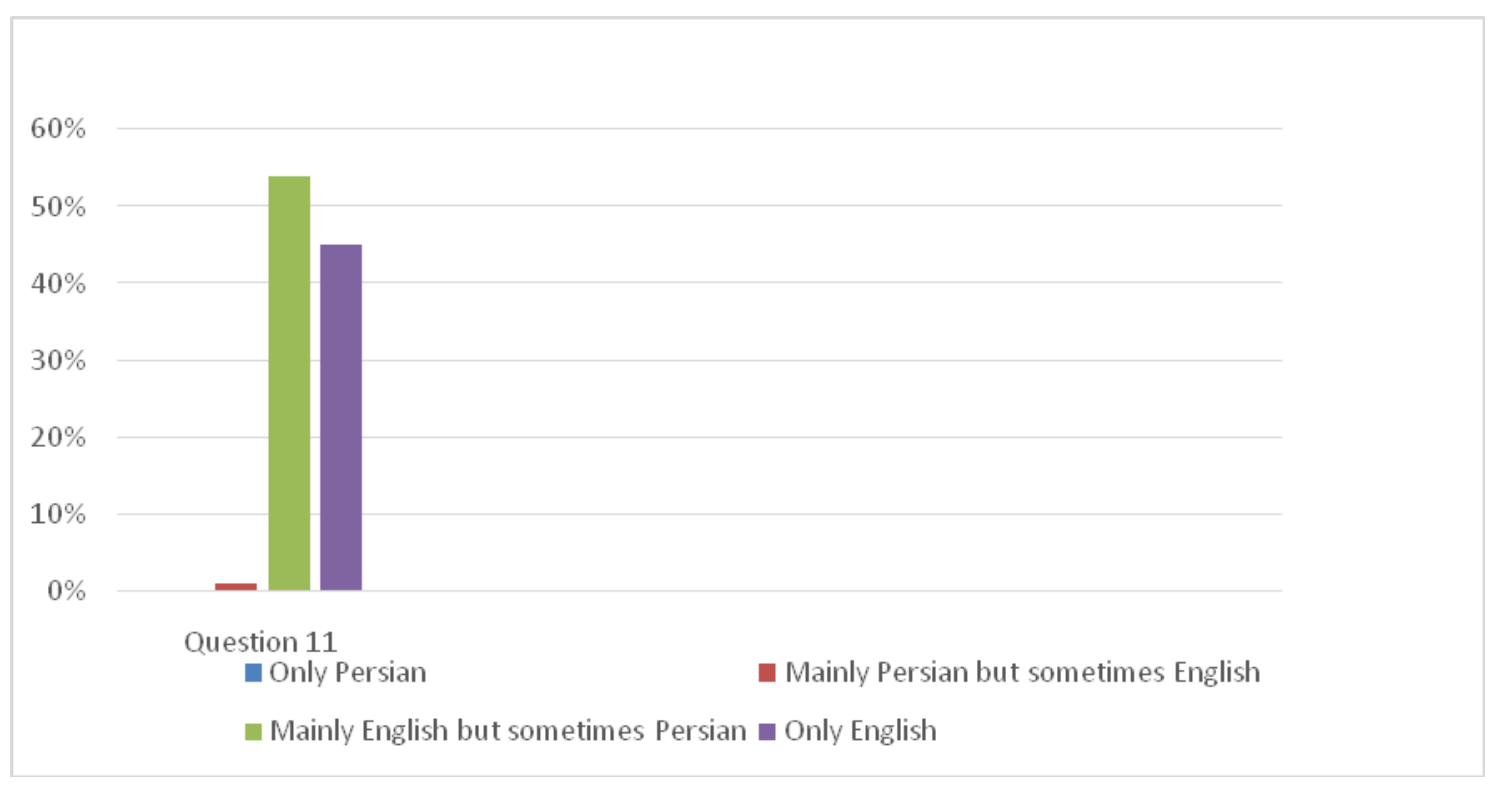

Figure 7. Schematic Representation of the Responses to Question 11

\section{Discussion}

This study sought to examine Iranian EFL university lecturers' practice of code switching in English classrooms as foreign language instruction. The results of this study, elicited from two sources of interview (from non-native English teachers) as well a questionnaire (distributed to students majoring in English) indicated that teachers' practice and application of code- switching during classrooms instruction was effective, and it was sometimes a benefit to EFL learners for further interaction. It appeared that the presentation of code-switching led to learners' overall improvement and better understanding of some unclear instructions, ambiguous explanations, difficult and abstract vocabulary, inner-classroom instructions given about some topics and subjects. It was, therefore, showed that learners' effort and task in learning some activities can be facilitated as they get involved or come to encounter contexts in which teachers periodically switched codes from 
English to Persian through either textual or visually-based enhancement practice because the technique of enhancement practice via code-switching fostered their learning activity in some fields.It is believed that one main reason for the adoption of code switching by teachersistofoster straightforwardness in communication and, hereby, interact more efficiently with the students; the teachers frequently practiced code switching since they realize that through code switching the meanings and concepts can be expressed more clearly. Concerning the effectiveness of this device in understanding difficult words, the respondents showed strong agreement. To clarify novel and problematic concepts, teachers repeatedly used to switch codes since it contributes to student's understanding as well as saving time. While repeating or strengthening any section of the lesson, defining or clarifying a terminology, the teachers often took advantage of code-switching. With regard to the usefulness of this device in clarifying the concepts and its effectiveness in explaining the unknown words and expressions,code-switching came to be practical.As new lessons, topics, and concepts are presented tothe learners, the teachers try to clarify the ambiguous points. Canagarajah (1995) commented on several strategies for elucidation like repetition, reformulation, clarification, exemplification and so on. Whenever a teacher implements any of such strategies, he/she may intentionally or unintentionally switch codes from English to Persian. Code-switching is regarded as an influential tool in clarifying any sort of misperception or misapprehension concerning any topic.It could be inferred that teachers need to handle approximately large classes. Code-switching can have an effective role in preserving discipline in a large class, achieving classroom discipline, giving instructions to the students about their desirable behavior in the classroom.Additionally, in a large class, the students differ significantly concerning their command of English. Further, it is too problematic to pay attention to individual students in such setting. Under this circumstance, code- switching can be employed to save time. In addition, it helps low- proficiency students to keep up with the more proficient students. At times, the teacher greeted the students by switching codes at the opening or closing of a class. In addition, it was revealed that there was an agreement between the teachers' code-switching patterns and the students' preferences.

The findings of this study are in line with the viewpoints of Sert (2005), Liebscher and Dailey-O'Cain (2005), Ellis (1994), Lai (1996), Widdowson (2003), and Rolin-Lonziti and Brownlie (2002), who favored applying code-switching in EFL classrooms. They all expressed positive view with code-switching and reported that they should be permitted whenever necessary with some learners in particular conditions. They also showed that teachers should consider code-switching as a benefit and that the employment of L1 (first language) is respectable and meaningful to motivate L2 acquisition. They define this type of classroom as a community of practice.

The findings of this study are also in accordance with the viewpoints of Johansson (2013), and Mujiono, Poedjosoedarmo, Subroto and Wiratno (2013) who examined and reported the main reasons for which teachers used code-switching in EFL classrooms as part of their regular instruction.

\section{Conclusion}


The findings of this study revealed that code-switching is an effective tool and as an educational technique in Iranian EFL classes and learning contexts occasionally applied by EFL lecturers and students to facilitate learning in particular conditions. Integration into EFL learning context,which sometimes involves the application of code-switching, leads to improved learning of some items and issues which need further clarification. This technique culminates in learners' better performancein particular learning contexts and conditions.Schweers's (1999) literature on code-switching has revealed the positive and facilitating functions of code-switching used by both the teachers and learners including explaining new vocabulary, relaxing the learners, explaining grammar, talking about class tasks and assessments, and establishing contact with learners.

Code-switching can be an advantageous way to exhibit solidarity with the interlocutor. To shape interpersonal relationships, become intimate with students, and influence constructively the affective domain of the students, the teacher regularly switches codes deliberately. This affective role of code switching is named by Gumperz (1982) as 'we code'. In Iran, as majority of the undergraduate level students come from average background, they feel inhibited in the classroom when a class is totally taken in English, particularly at the outset of the undergraduate courses; therefore, switching codes by teachers through a range of activities including telling jokes, talking about personal experiences, sharing ideas with learners can be leading to the creation of related and comfortable setting in the classroom.

\section{References}

Bista, K. (2010). Factors of Code Switching among Bilingual English Students in the University Classroom: A Survey. English for Specific Purposes World, 29(9).

Canagarajah, S. (1995). Functions of code-switching in ESL Classrooms: Socializing Bilingualism in Jaffna. Journal ofMultilingual and Multicultural Development, 6(3), 173-195. http://dx.doi.org/10.1080/01434632.1995.9994599

Cook, V. (1991). Second language learning and language teaching. Melbourne: Edward Arnold/ Hodder Headline Group.

Cook, V. (2001). Using the first language in the classroom. Canadian ModernLanguage Review, 57(3), 403-423. http://dx.doi.org/10.3138/cmlr.57.3.402

Duff, P., \& Polio, C. (1990). How much foreign language is there in the foreign language classroom? The Modern Language Journal, 74(2), 154-166. http://dx.doi.org/10.1111/j.1540-4781.1990.tb02561.x

Edstorm, A. (2006). L1 use in the L2 classroom: One teacher's self-evaluation. The Canadian Modern Language Review, 63(2), 275- 292. http://dx.doi.org/10.3138/cmlr.63.2.275

Ellis, R. (1994). The study of second language acquisition. Oxford: Oxford University Press.

Gumperz. \& Hernandez-Chavez. (Ed.). (1972). The Encyclopedia of language and linguistics. Oxford: Pergamon press. 
Heller, M. (Ed.).(1988). Code-switching: Anthropological and Sociolinguistic Perspectives. Berlin: Mouton de Gruyter. http://dx.doi.org/10.1515/9783110849615

Hopkins, D. (1993). ATeachers' Guide to Classroom Research. Buckingham: Open University Press.

Johansson, B., \& Svedner, P. O. (2010). Examensarbeteilärarutbildninge. Uppsala: Kunskapsföretaget AB.

Johansson, S. (2013). Code-switching in the English classroom: What teachers do and what their students wish they did? Degree project, Karlstads University, Faculty of Arts and Social Sciences.

Lai, M. (1996). Using the L1 sensibly in English language classrooms. Retrieved May 25, 2011, from http://sunzi1.lib.hku.hk/hkjo/view/48/4800045.pdf

Liebscher, G. \& Dailey-O'Cain, J. (2005). Learner Code-switching in the Content-Based Foreign Language Classroom. The Modern Language Journal [e-journal] 89, (ii). Available through: Academic Search Elite. [Accessed 4 November 2010].

Lin, A. (2013). Classroom code-switching: Three decades of research. AppliedLinguistics Review, 4(1), 195-218. http://dx.doi.org/10.1515/applirev-2013-0009

Mujiono, L., Poedjosoedarmo, S., Subroto, E., \&Wiratno, T. (2013). Code-Switching in English as foreign language instruction practiced by the English lecturers at universities. International Journal of Linguistics, 5(2), 46-65. http://dx.doi.org/10.5296/ijl.v5i2.3561

Milroy, L., \& Muysken, P. (1995). One speaker, two languages: Cross-disciplinaryperspectives on code-switching. Cambridge: Cambridge University Press. http://dx.doi.org/10.1017/CBO9780511620867

Mugla, E. Ü., \&Seedhouse, P. (2005). Why that, in that language, right now? Code switching and pedagogical focus. International Journalof Applied Linguistics, 15(3), 302-325. http://dx.doi.org/10.1111/j.1473-4192.2005.00093.x

N. Hassan. (Ed.). (2009). English in Southeast Asia: Prospects, perspectives and possibilities. Kuala Lumpur: University Malaya Press.

Polio, C. G., \& Duff, P. A. (1994). Teachers' language use in university foreign language classrooms: A qualitative analysis of English and target language alternation. The Modern Language Journal, 76(3), 313-326. http://dx.doi.org/10.1111/j.1540-4781.1994.tb02045.x

Qian, X., Tian, G., \& Wang, Q. (2009). Code-switching in the primary EFL classroom in $\begin{array}{lllll}\text { China: } \quad \text { Two } & \text { case } & \text { studies. } & \text { System, }\end{array}$ http://dx.doi.org/10.1016/j.system.2009.09.015

Rababah, G. A. (2002). Strategic competence and language teaching. Available at: http://www.eric.ed.gov/PDFS/ED472697.pdf [Accessed 10 December 2010]. 
Rolin-Ianziti, J., \&Brownlie, S. (2002). Teacher use of learners' native language in the foreign language classroom. The Canadian Modern Language Review, 58(3), 402-426. http://dx.doi.org/10.3138/cmlr.58.3.402

Schweers, C.W. (1999). Using L1 in L2 classroom. The English Teaching Forum, 37(2).

Sert, O. (2005). The functions of code switching in ELT classrooms. The Internet TESL Journal, XI(8), August 2005 http://iteslj.org/

Simon, D. (2001). Towards a new understanding of code-switching in the foreign language classroom. In Jacobson, D. (Ed.), Code-switching worldwide II (p.311-342). Berlin, New York: Mouton de Gruyter. http://dx.doi.org/10.1515/9783110808742.311

Skiba, R. 1997. Code Switching as a Countenance of Language Interference. The Internet TESL Journal, 3, $10<$ ttp://iteslj.org/Articles/Skiba-CodeSwitching.html

Thomas, S, G., 2001. Language contact, an introduction. [e-book] Edinburgh: Edinburgh University Press Ltd. Available through: http://books.google.com/. [Accessed 10 December].

Tien, C \& Liu, K. (2006). Code-switching in two EFL classes in Taiwan. In A. Hashim \&N. Hassan (Eds.). English in Southeast Asia: Prospects, perspectives and possibilities. Kuala Lumpur: University Malaya Press.

Trudgill, P. (2000). Sociolinguistics. London: Penguin

Valdes-Fallis, G. (1978). Code switching and the classroom teacher. ERIC Clearinghouse on Languages and Linguistics, 4, 1-31. Retrieved from http://files.eric.ed.gov/fulltext/ED153506.pdf

Widdowson, M. (2003). Exploring identity through code-switching: A poststructuralist approach. Alternation, 11(2), 144-164.

Yule, G.(2010). The study of language, 4th edition. [e-book]. Cambridge: Cambridge University Press. http://dx.doi.org/10.1017/CBO9780511757754

\section{Appendix 1}

Interview questions

Male Female

What are your subject(s) beside English?

How many years have you been teaching?

1. What do you think about the use of Persian in the English classroom, in general?

2. In what situations do you choose to speak Persian?

3. Are there times and situations when you always speak Persian? When and why? 
4. Are there advantages in changing the language to Persian in your teaching?

5. Are there times and situations when you never speak Persian or try extra hard not too?

When and why?

6. Are there disadvantages in changing the language to Persian when you teach?

7. Are there times when you speak Persian when it was not planned ahead? When does this occur? What situations make you switch into Persian? Why do you use Persianin those situations?

8. Is your choice of language different if you are talking to the whole class or with a single student?

9. Is your choice of language different depending on which one of your classes you are teaching?

10. Are there advantages when students switch to Persian when you teach?

11. Are there disadvantages when students switch to Persian when you speak?

12. Are there situations when you encourage students to speak Persian?

13. In the new syllabus for English it is said that teaching should as far as possible beconducted in English. What has this new guideline meant for your teaching?

\section{Appendix 2}

This questionnaire is set to research what language you as a student prefer in the English classroom and is a part of my C-essay in English. The participation will be made anonymously and is also voluntarily. Thank you for your help!

- I am

O Male OFemale

My mother tongue is

OEnglish QPersian Osther

"Next Side"

1. When my teacher explains grammar I want her or him to use

O English 


\section{Macrothink}

O Persian

O A combination of both

2. When my teacher gives us instructions I want her or him to use

O English

O Persian

O A combination of both

3. When my teacher informs us about a test I want her or him to use

O English

O Persian

O A combination of both

4. When my teacher gives me my result on a test I want her or him to use

\section{O English}

O Persian

O A combination of both

5. When my teacher and I discuss my grade I want her or him to use

O English

O Persian

O A combination of both

6. When I don't understand instructions I

O Ask a friend in Persian

O Ask a friend in English

O Ask the teacher in Persian

O Ask the teacher in English

O I don't ask

7. When my teacher speaks Persian during English class I feel that I

O Understand better

O Understand less

O Understand as well when he or she speaks English

8. When I ask a question in Persian I want the teacher to answer me in

O English

O Persian

O Both are okay

9. If my teacher explains something that I don't understand I want him or her to

O Repeat the question

O Explain again in English but in a different way 
O Explain in Persian

10. When I am in English class I want my teacher to

O Make me speak more English

O Allow me to speak Persian

11. My teacher normally speaks

O Only Persian

O Mainly Persian but sometimes English

O Mainly English but sometimes Persian

O Only English 